\title{
Development of Web-Based GIS Alert System for Informing Environmental Risk of Dengue Infections in Major Cities of Pakistan
}

\author{
Naureen Zainab ${ }^{1}$, Aqil Tariq ${ }^{2, *}$ (ID), Saima Siddiqui ${ }^{3}$ \\ ${ }^{1}$ Department of Computer Software Engineering, Military College of Signals, National \\ University of Science and Technology (NUST), Islamabad, 44000, Pakistan \\ ${ }^{2}$ State Key Laboratory of Information Engineering in Surveying Mapping and Remote \\ Sensing (LIESMARS), Wuhan University, Wuhan, 430079, China \\ ${ }^{3}$ Department of Geography, University of Punjab, Lahore, 54590, Pakistan
}

Received 23 November 2020/Revised 10 March 2021/Accepted 19 March 2021/Published 25 April 2021

\begin{abstract}
Dengue is one of the emerging major public health problems, and its incidence varies with climate conditions. It affects millions of people's lives owing to unusual socioeconomic conditions and epidemiological factors. This study was designed to build a web-based GIS alert system for dengue data management and analysis which would centralize information and make it accessible to all relevant stakeholders before, during, and after crises. Three geographical regions were selected in this study. The user interface of the dengue alert system was developed based upon MapGuide. Results indicate that risk level was mainly associated with Breteau Index. Karachi and Lahore were at their highest risk, i.e., level 4. Islamabad and Chakwal were also at the highest risk, i.e., level 4. Attock had high risk, i.e., level 3 followed by Haripur with minimal level 1. The high Breteau Index showed a direct relationship to high potential transmission of dengue outbreaks, a more significant peak of dengue was the result of monsoons, while smaller peaks were observed due to domestic water storage. Hence, it was concluded that monsoon is the best suitable season for the development of dengue. Web-Based GIS Alert System for dengue data management and analysis was developed, centralizing information and making it accessible to all relevant stakeholders before, during \& after a crisis. This program creation will provide a more analytical forum for advising multiple levels of risk and an experimental method for measuring the effect of different factors on risk level distribution by adjusting the component's weighting.
\end{abstract}

Keywords : Dengue; GIS analysis; GUI; Alert system; Breteau index; Weighted overlay

\section{Introduction}

Dengue is a mosquito-borne virus whose prevalence differs with temperature and weather (Chang et al., 2009; Gubler, 2006). Dengue is rising as one of Pakistan's most significant public health problems (Asif et al., 2013). In October 2005, after ten years, dengue affected Karachi again, and 21 deaths were reported out of 103 confirmed cases (Mukhtar et al., 2011).

*Corresponding author.

Email address : aqiltariq@whu.edu.cn (Aqil Tariq) 
The year 2011 was Pakistan's worst year for dengue. In 2013 the most affected area was the dengue fever (DF) outbreak in Pakistan. Aedes-aegypti and Aedes-albopictus is considered to be the main dengue vectors in South Asia, including Pakistan. The identification of disease outbreaks is very significant (Sirisena et al., 2017). Epidemics are silent in contrast to explosions. Outbreaks kill or cause sickness before detection (Kahn et al., 1975). Disease outbreaks can easily cause such hurt, and they can spsread rapidly, too. In the worst scenario, the window of opportunity to minimize this harm could be limited to a few days (Thompson et al., 2016). The United States of America spends billions of dollars a year on different forms of safety surveillance. The essential expenses include patient infection control, public health surveillance (PHS), air and water inspection, preparation, improved public health, and science services in information technology (Kahn et al., 1975). Proper and prompt treatment of incidents of sickness can save many meaningful humans lives.

The Breteau Index calculates the number of positive containers per hundred surveyed homes, which in turn represents the distribution of Aedine mosquitoes, the dengue vector ( Udayanga et al., 2018). An alert system was established in Pakistan from a synthesis of geospatial data on the Breteau Map. The interrelationship was rendered between the Breteau Index and the temperature. It forms the basis for creating weighted overlays to determine risk levels (Attaway et al., 2016). Dengue Alert System generally predicts four different risk levels for the risk of dengue infections, i.e., highest, high, medium, and minimal ( Olubadewo-Joshua \& Ugom, 2019; Tran et al., 2020). Hence, a Web-based application was created from a synthesis of geospatial data related to Breteau Index and temperature effect in Pakistan's major cities. Using various weighting factors on the previous history, appropriate weighting factor was evaluated and used to generate the alert for informing environmental risk of dengue infection in major cities of Pakistan. It forms the basis for creating weighted overlays to determine levels of risk. The weighting can be adjusted to adjust alarm device sensitivity (Bowman et al., 2014).

Every year Pakistan experiences a lot of rain during the mild summer (monsoon) season. The daytime temperature is greater than the night temperature. Its good climatic conditions for the growth of dengue mosquitos. In this study, we target six major cities of Pakistan because Pakistan faces a lot of problems in these regions every year. In this study, we clearly describe the Spatio-temporal distributions of dengue cases. The study is novel because its first time correlates the local predominant conditions with dengue prevalence and builds a web-based GIS alert system. Therefore, this study was designed to build a web-based GIS alert system for dengue data management and analysis which would centralize 
information and make it accessible to all relevant stakeholders before, during, and after crises.

\section{Methods}

\subsection{Study Area}

The study area includes Rawalpindi, Haripur, Attock, Chakwal, Lahore, and Karachi (figure 1). All metropolitan regions are located in different latitudes and longitude in Pakistan. These cities' climate is characterized by four seasons: dry, wet, hot, and cold (Abbas, 2013). Rawalpindi and Lahore experience a monsoonal environment with rainy, hot summers and cool dry winters (wet and dry season); rainfall is typical of Pakistan's semi-arid region. Karachi also receives Monsoon rainfall, but the landscape is different compared to Rawalpindi and Pakistan (Burney et al., 2018). Karachi Harbor is a secure and majestic natural harbor on the shores of which the town is located. A low-lying coastal area stretches along the harbor's edge. The Malir River, a seasonal current, flows through the eastern part of the city, and the seasonal Layari River runs through the northern section that is most densely populated. Several ridges and small hills occur; the maximum elevation, Mango Pir, is 585 feet high.

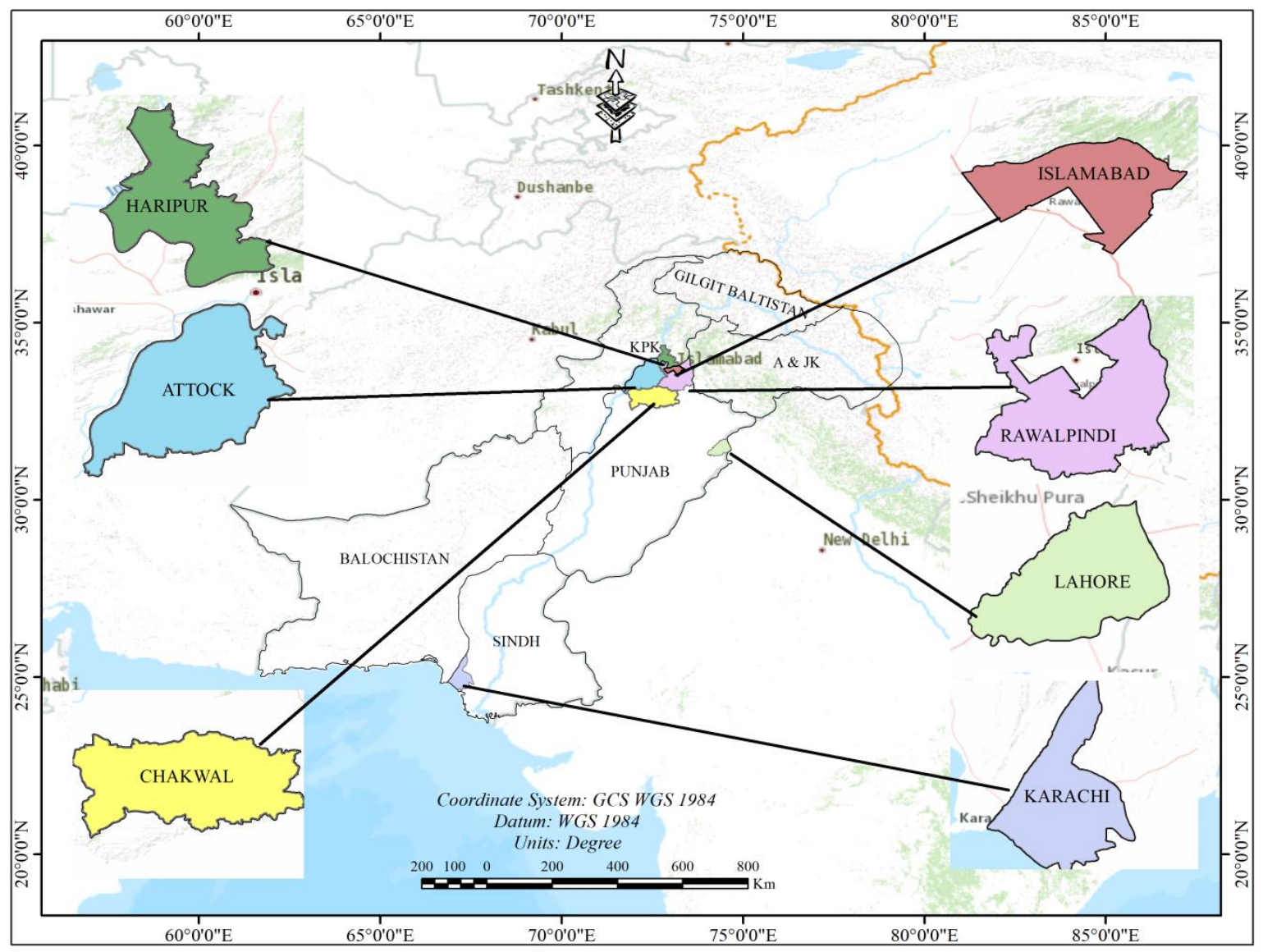

Figure 1. Study area of dengue epidemic-prone districts in Pakistan 


\subsection{System Design, Development, and Assumption}

The alert system had been developed to forecast the risk of infection with dengue. It was presumed that the two variables that were used in the method, namely temperature and Breteau Scale, were strongly associated with dengue fever infection sensitivity and are of significant geographical significance (Kaya et al., 2019).

\subsection{Data Source}

Data on Breteau Index and affected people from 2006 to 2013 were collected from the National Institute of Health and Governments Health Departments. The monthly temperature data from 2006 to 2013 was acquired from the Pakistan Meteorological Department of Islamabad.

\subsection{Weighted Overlay}

A web-based application was developed from a synthesis of geospatial data related to the Breteau Index and temperature (Cetin et al., 2019).Using various weighting factors on the previous history, appropriate weighting factor was evaluated and was used to generate the alert for informing environmental risk of dengue infection in major cities of Pakistan. The Breteau Index was calculated according to Eq. (1) as described by Gubler et al. (2014), while the risk level was calculated based on the formula generated as Eq. (2).

Breteau index $(\mathrm{BI})=\frac{\text { Number of positive containers }}{\text { houses inspected }} \times 100$

Risk level $=\mathrm{BI} \frac{(60+\text { temperature })}{40}$

When the Breteau Index value is zero, the risk level will be zero too, even in the case of high temperature. For instance, in similar temperatures in two different cities, two different risk levels can be observed due to different Breteau indexes.

\subsection{Risk Levels}

Dengue risk levels were classified (Table 1) into four different groups based on the developed formula of the risk level. The Breteau Index against these four risk levels is also analyzed. It was assumed that if Breteau Index is high, then the risk level is also high as Breteau Index and risk levels are directly proportional to each other (Table 2). 
Naureen Zainab et al. / Geosfera Indonesia 6 (1), 2021, 77-95

Table 1. Risk levels (Gubler et al., 2014)

\begin{tabular}{cc}
\hline Classification & Risk level \\
\hline Level 1 & $0<$ Risk level $<=300$ \\
Level 2 & $301<=$ Risk level $<=600$ \\
Level 3 & $600<=$ Risk level $<=1200$ \\
Level 4 & Risk level $>1200$ \\
\hline
\end{tabular}

Table 2. Breteau index according to risk levels (Gubler et al., 2014)

\begin{tabular}{ccc}
\hline Classification & Risk level & Breteau Index \\
\hline Level 1 & $0<$ Risk level $<=300$ & $0<\mathrm{BI}<=4$ \\
Level 2 & $301<=$ Risk level $<=600$ & $5<=\mathrm{BI}<=9$ \\
Level 3 & $600<=$ Risk level $<=1200$ & $10<=\mathrm{BI}<=19$ \\
Level 4 & Risk level $>1200$ & $\mathrm{BI}>=20$ \\
\hline
\end{tabular}

\subsection{Prevention or Management of Dengue Borne Vector for Confined Risk Level}

The adoption of integrated pest management did the management of dengue vectors at confined four risk levels. Integrated pest management is the pest population's level to check the pest below the economic injury level using all possible control measures (Novotny et al., 2007). Recommendations regarding each risk level were given on the basis of IPsM strategies. There are specific preventive and control measures recommended for each alert level shown in Table 3.

Table 3. Preventive measures against each risk level (Novotny et al., 2007)

\begin{tabular}{|c|c|c|c|}
\hline Classification & Breteau Index & Risk Level & Actions \\
\hline Level 1 & $0<\mathrm{BI}<=4$ & $\begin{array}{c}0<\text { Risk } \\
\text { level<=300 }\end{array}$ & $\begin{array}{l}\text { Intimately monitor the sanitary condition to prevent } \\
\text { and manage the various breeding places. } \\
\text { Weekly inspection of breeding places and likely to } \\
\text { eradicate immediately. } \\
\text { Try to eliminate the fresh and stagnant water pounds. }\end{array}$ \\
\hline Level 2 & $5<=\mathrm{BI}<=9$ & $\begin{array}{l}301<=\text { Risk } \\
\text { level }<=600\end{array}$ & $\begin{array}{l}\text { The public is advised to monitor the breeding places } \\
\text { efficiently within } 3-4 \text { days and eliminate their } \\
\text { possible infesting or breeding heaven within their } \\
\text { premises. }\end{array}$ \\
\hline Level 3 & $10<=\mathrm{BI}<=19$ & $\begin{array}{c}600<=\text { Risk } \\
\text { level }<=1200\end{array}$ & $\begin{array}{l}\text { Along with regular monitoring, eliminate all possible } \\
\text { breeding potential through conducting special } \\
\text { operations on a regular basis. } \\
\text { Launch task-oriented forces to create awareness } \\
\text { among people regarding dengue elimination } \\
\text { programmed. }\end{array}$ \\
\hline Level 4 & $\mathrm{BI}>=20$ & $\begin{array}{c}\text { Risk } \\
\text { level>1200 }\end{array}$ & $\begin{array}{l}\text { Launch a task-oriented force to create awareness } \\
\text { among people regarding dengue elimination } \\
\text { programmed and give them responsibilities to restrain } \\
\text { the potential breeding places by allotting them } \\
\text { specific territories. Private competitive pest control } \\
\text { and management contractor must be employed to } \\
\text { control and eradicate the arising potential mosquito } \\
\text { problem. }\end{array}$ \\
\hline
\end{tabular}




\subsection{Conceptual Design}

The present study's concept was to build a Web-Based GIS Alert System both online and offline for dengue data management and analysis, centralizing the information and making it accessible to all relevant stakeholders before, during, and after a crisis. The system aimed to ensure timely availability of information on health care services. The project data were mapped accurately and with geographic features displayed. Maps were drawn according to pre-set parameters in the present framework, and then the web browser showed the map in a .jpeg format. The users can create and display a new map by adjusting the parameters. On the server-side, this sort creates a heavy load. The server-side had regional info, GIS tools, and a system with hundreds of complex reports on the interface (Cetin, 2015). The systematic conceptual diagram of the Web-Based GIS Alert System is shown in Figure 2.

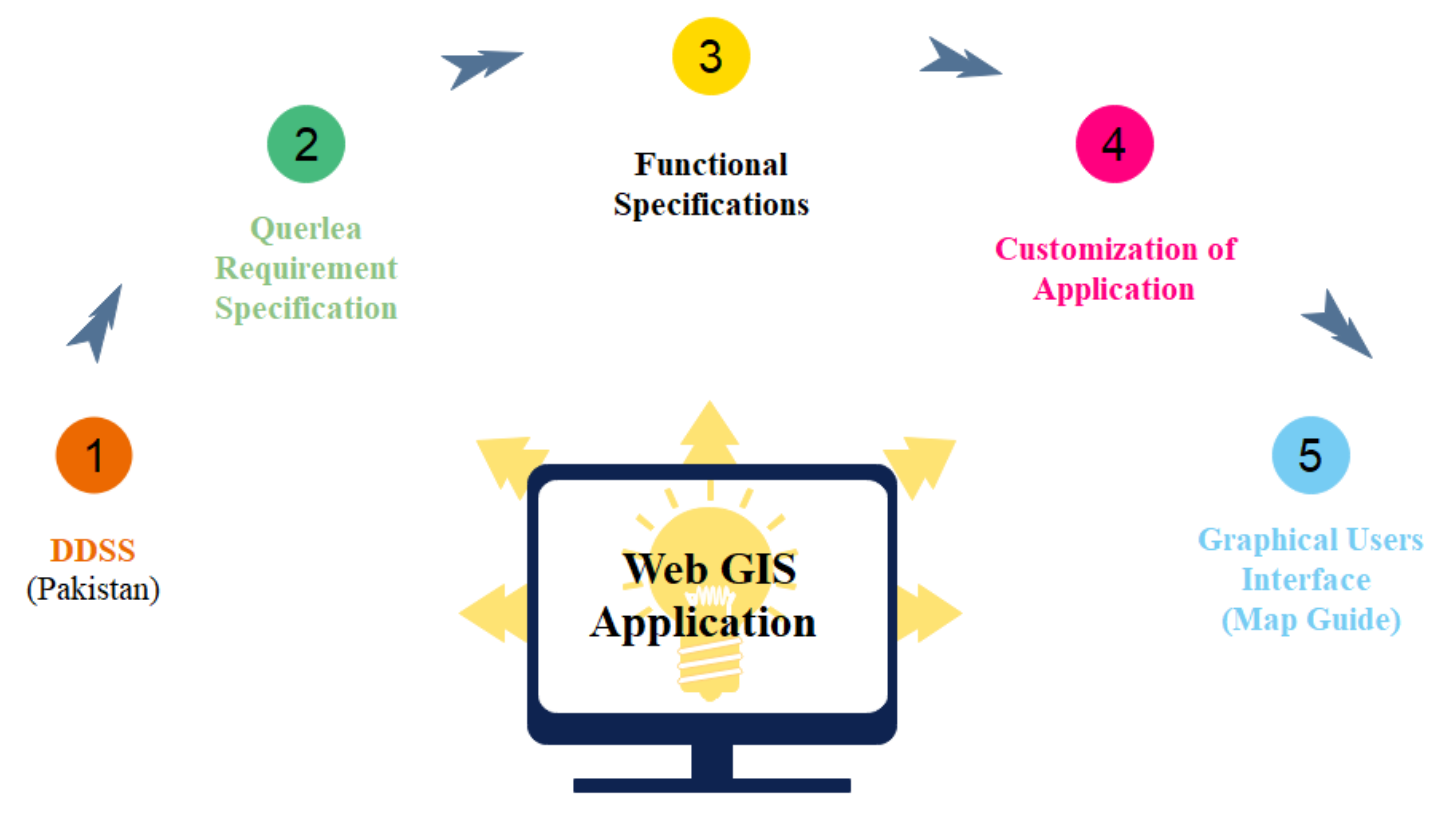

Figure 2. Conceptual Design of Web-Based GIS Alert System.

\subsection{User Interface (UI)}

MapGuide Maestro is a MapGuide open-source map authoring tool. MapGuide Maestro strives to support the capabilities of the open-source application MapGuide. Both spatial and non-spatial details have been contained in SQL Server Express, which is a free database service that fits well with any web application platform (Zavlavsky, 2000). The Graphical User Interphase (MapGuide) was systematically developed, as shown in figure 3. 
Naureen Zainab et al. / Geosfera Indonesia 6 (1), 2021, 77-95

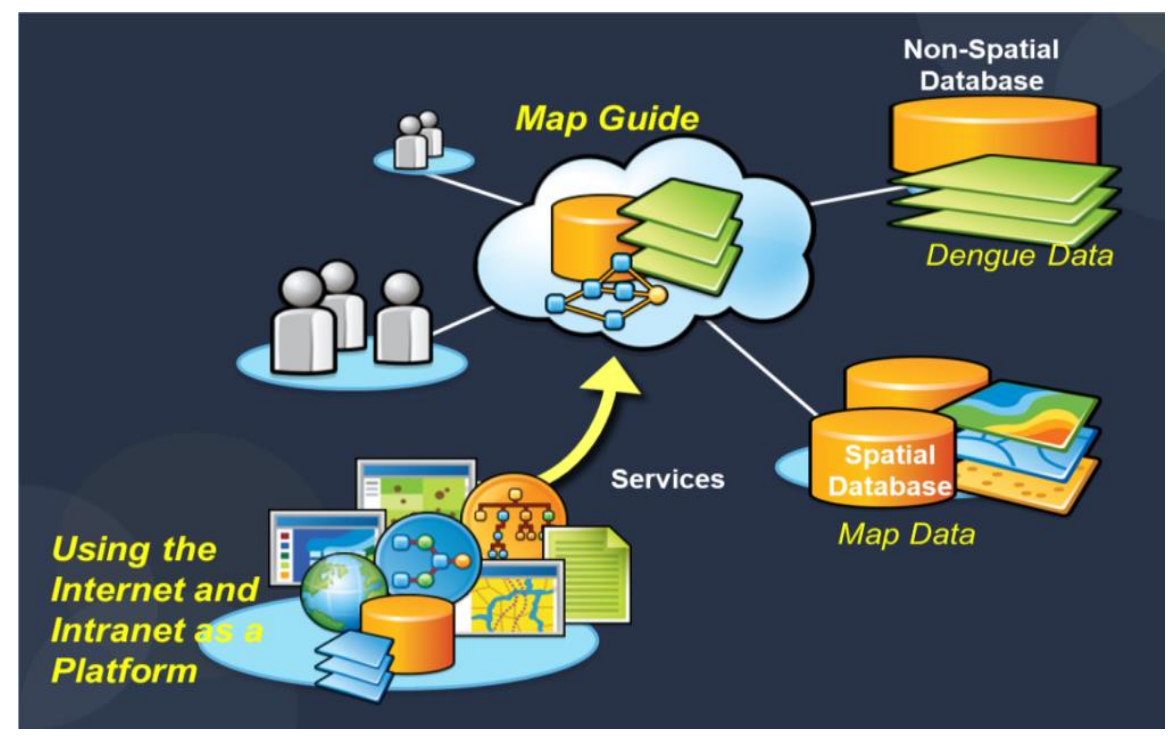

Figure 3. Graphical User Interphase (MapGuide)

\subsection{Component of Web-Based GIS Alert System}

Three components of the Web-Based GIS Alert System (figure 4) were used as:

(1) Dengue Information Databases

(2) GIS Layers and Maps

(3) Queries and Reports

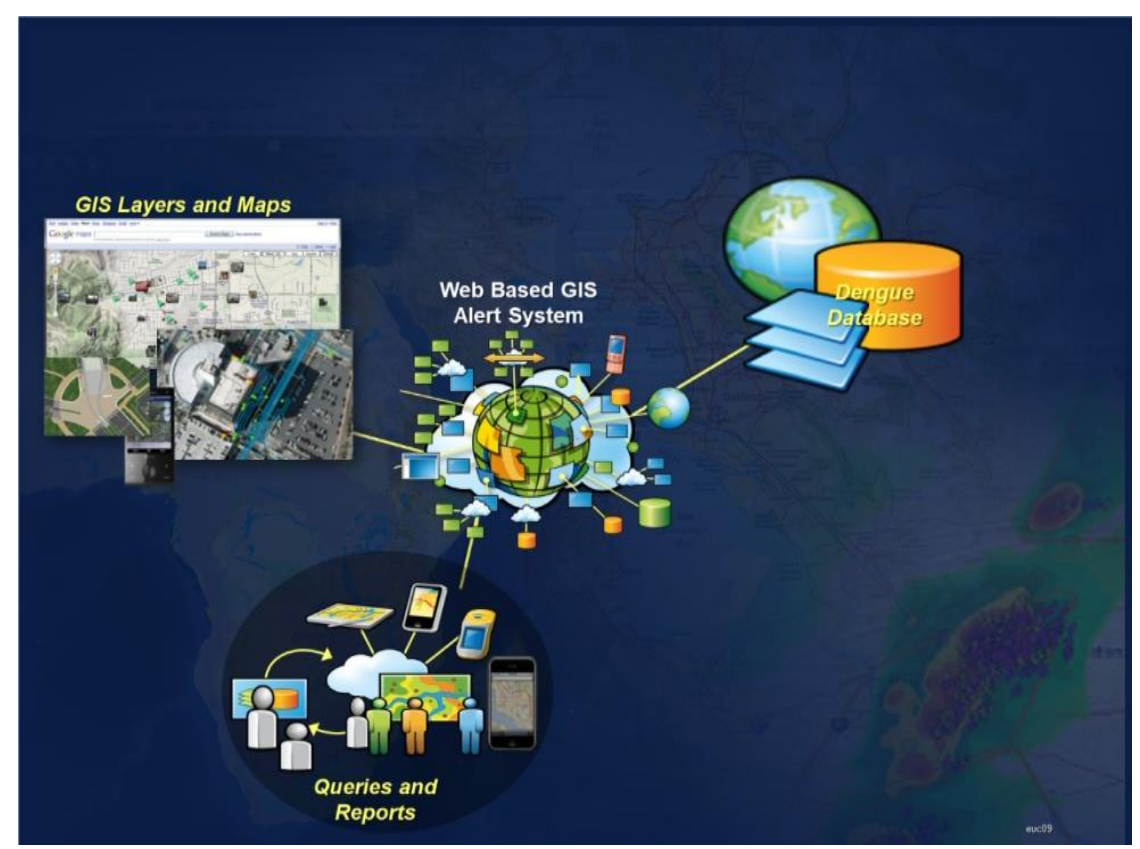

Figure 4. Components of Web-Based GIS alert system

Overall, the system describes the risk levels of dengue infection in major cities of Pakistan, classifying them into three geographical regions. A web-based application was created from a synthesis of geospatial data related to the Breteau index and temperature effect in Pakistan's major cities. Currently, statistics on the Breteau Index and temperature are 
displayed in a table format that is difficult for interpretation by general users. This project allows the visualization of the Breteau Index and temperature information in a spatial pattern and association with four risk levels, which enhances public awareness. Dengue Alert System describes the risk level of dengue infections from 2006 to 2013 in major cities of Pakistan. It can also predict the current risk level of dengue in any district of Pakistan. It can predict four different risk levels for the risk of dengue infections, i.e., highest, high, medium, and minimal.

\section{Results and Discussion}

\subsection{Temporal Changes in Temperature and Breteaux Index}

A good association between the two variables has been identified from the temporal change in temperature and the Breteau Scale (Bozdogan et al., 2021). Higher Breteau Index focused primarily in the summer and autumn when higher temperatures prevailed. Results shown in Figure 5a indicate the temporal changes in Breteau Index in September 2010 in selected study sites. The Breteau Index of Lahore and Islamabad represented by Green color was high. The Breteau Index of Karachi denoted by Blue color was medium. The Breteau Index of Chakwal and Haripur represented by Yellow color was minimal, and the Breteau Index of Attock represented by Gray showed no risk. Similarly, the temporal changes in temperature in major cities of Pakistan Figure 5b indicate that Karachi had high temperature while the remaining cities showed low temperature.

The high temperature was represented by Dark Gray color, and Low temperature was represented by Light Gray. The effect of temperature on the weighted overlay product can be calculated when the temperature and the Breteaux index are overlaid. The temperature was not considered to be the main factor deciding the level of risk according to the given weighting, and when the Breteau Scale equals zero, the risk level was also zero, irrespective of the temperature increase. The cities with a high Breteau Index are at a higher risk level. Lahore and Islamabad's temperature was low compared to Karachi, but they had a high-risk level due to the high Breteau Index. Breteau Index of Attock was zero, so there was no risk; however, the Attock temperature was $28^{\circ} \mathrm{C}$, similar to Chakwal $27.6^{\circ} \mathrm{C}$. 


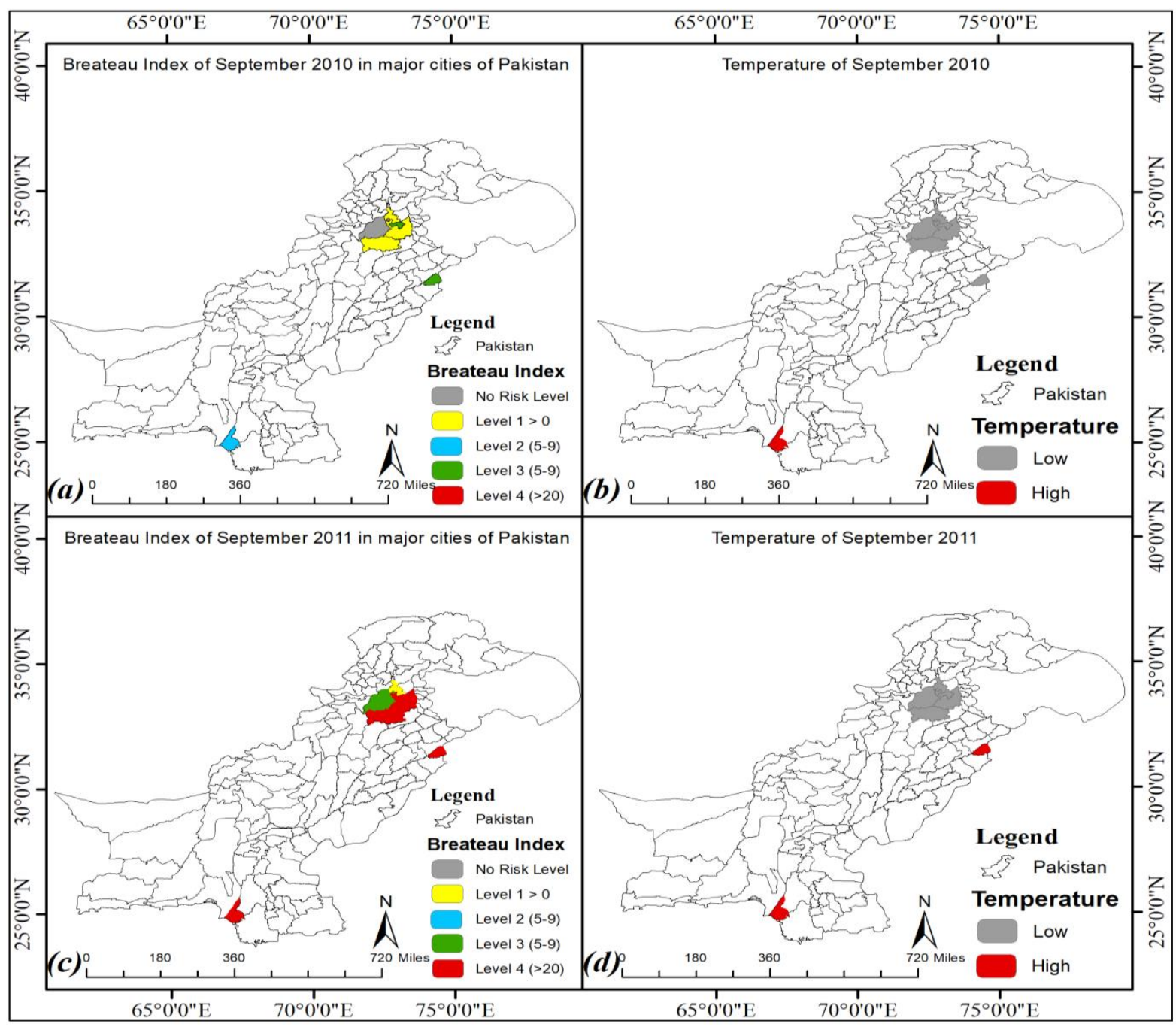

Figure 5a. Breteau Index of September 2010 in major cities of Pakistan, Figure 4b. Temperature of September 2010 in major cities of Pakistan, Figure 4c. Breteau Index of September 2011 in major cities of Pakistan, Figure 4d. Temperature of September 2011 in major cities of Pakistan.

Figure 5c and Figure 5d show the Breteau Index and temperature of September 2011 in selected study sites. Attock and Haripur very high followed the Breteau Index of Karachi, Lahore, Islamabad, Rawalpindi, and Chakwal. The temperature of Karachi and Lahore was high as compared to other cities. Figure 5d represents that Karachi and Lahore were at their highest risk and the temperature of these two cities was also high. Rawalpindi, Islamabad, and Chakwal were also at the highest risk, but they had a low temperature as compared to Karachi and Lahore. Attock had high risk, and the temperature was low. Haripur showed minimal risk and had a low temperature. Rawalpindi and Attock's temperature showed a similar trend but had different risk levels due to different Breteau Index.

Web-based generated map of the Risk Levels of Dengueshows that risk level was high in those cities which had high Breteau Index. Results indicate that Karachi and Lahore were at their highest risk, i.e., level 4. Islamabad and Chakwal were also at the highest risk, 
i.e., level 4. Attock had high risk, i.e., level 3 followed by Haripur with minimal level 1. Hence, it is concluded that risk level was mainly associated with Breteau Index, if Breteau Index was high, then the risk level was also high, so this is the main reason for which the highest weightage is assigned to the Breteau Index (Gungor et al., 2020). Temperature also plays a significant role because the risk level was high in mostly the summer months, which had a high temperature. If the temperature was high, mosquito's growth rates were also high because high temperature helps in breeding Aedes aegypti and Aedes albopictus mosquitoes.

3.2 Peaks of Dengue Based on the Analysis of Risk Levels from 2006- 2013 in Major Cities of Pakistan

Results from the analysis of dengue risk levels from 2006 to 2013 in major cities of Pakistan indicated that the high risk of dengue from 2006 to 2013 was mostly observed in the month of September, October, and November (Table 4). The dengue-related deaths were reported between the months from September to November. Dengue case-load registered during these months, and the reports declined rapidly during and after December. The high Breteau Index showed a major direct relationship to the high potential transmission of dengue outbreaks in the study sites. Two peaks of dengue were shown in the form of risk levels. The formation of a more significant peak of dengue resulted from monsoon rains in which water was filled at the low-lying places. Smaller peaks of dengue were formed in the dry season due to domestic storage of water. It was seen that transmission of dengue during the monsoon and after monsoon was maximum than that of the dry season. Finally, it was concluded that monsoon is the best suitable season for the reproduction, fecundity, survival, growth, and development of dengue.

Dengue fever is estimated to affect 50 to 100 million people with $1 / 2$ million lifethreatening infections globally in a year as of 2010. It has risen 30-fold significantly in frequency between 1960 and 2010. In Pakistan in the year 2010, there were more than 7000 positive confirmed cases of dengue.With rising epidemics, dengue fever has become a significant disease in Pakistan. Given Pakistan's government's efforts, especially in Punjab, the high treatment cost has hindered Pakistan's ability to control epidemics. Dengue-fever mortality in Pakistan in the summer of 2011 was over 300 people, and epidemic incidence was over 14,000 infections. The outbreaks mainly occurred in the region of Lahore, Punjab, Pakistan. 
Table 4. Results from the analysis of dengue risk levels from 2006 to 2013 in major cities of Pakistan

\begin{tabular}{|c|c|c|c|c|c|c|c|c|c|}
\hline City & Dengue Risk & 2006 & 2007 & 2008 & 2009 & 2010 & 2011 & 2012 & 2013 \\
\hline \multirow{4}{*}{ 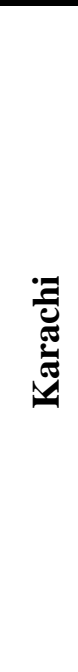 } & Duration & $\begin{array}{c}\text { Jan } \\
\text { Apr } \\
\text { Jul } \\
\text { Aug }\end{array}$ & - & $\begin{array}{c}\text { Jan, } \\
\text { Sep } \\
\text { to } \\
\text { Dec }\end{array}$ & $\begin{array}{l}\text { Aug } \\
\text { to } \\
\text { Dec }\end{array}$ & $\begin{array}{c}\text { Jan } \\
\text { Apr } \\
\text { Aug } \\
\text { to } \\
\text { Dec }\end{array}$ & $\begin{array}{l}\text { Jan } \\
\text { Apr } \\
\text { to } \\
\text { Dec }\end{array}$ & $\begin{array}{c}\text { Jan } \\
\text { to } \\
\text { Dec }\end{array}$ & $\begin{array}{c}\text { All } \\
\text { over } \\
\text { the year }\end{array}$ \\
\hline & Minimum & $\begin{array}{c}\text { Jan } \\
\text { Apr } \\
\text { Jul } \\
\text { Aug } \\
\end{array}$ & $\begin{array}{l}\text { Jul } \\
\text { Dec }\end{array}$ & Jan & $\begin{array}{c}\text { Jan } \\
\text { Aug } \\
\text { Sep } \\
\text { Dec }\end{array}$ & $\begin{array}{l}\text { Jan } \\
\text { Apr } \\
\text { Aug } \\
\text { Dec } \\
\end{array}$ & $\begin{array}{c}\text { Jan } \\
\text { Apr } \\
\text { to } \\
\text { Jul } \\
\end{array}$ & $\begin{array}{c}\text { Jan } \\
\text { to } \\
\text { Sep }\end{array}$ & $\begin{array}{c}\text { Jan } \\
\text { to } \\
\text { Aug } \\
\text { Dec }\end{array}$ \\
\hline & Moderate & Sep & Sep & $\begin{array}{l}\text { Sep } \\
\text { Dec }\end{array}$ & - & Sep & $\begin{array}{l}\text { Aug } \\
\text { Nov } \\
\text { Dec }\end{array}$ & Dec & Sep \\
\hline & Highest & $\begin{array}{l}\text { Oct } \\
\text { Nov }\end{array}$ & $\begin{array}{l}\text { Oct } \\
\text { Nov }\end{array}$ & $\begin{array}{l}\text { Oct } \\
\text { Nov }\end{array}$ & $\begin{array}{l}\text { Oct } \\
\text { Nov }\end{array}$ & $\begin{array}{l}\text { Oct } \\
\text { Nov }\end{array}$ & $\begin{array}{l}\text { Sep } \\
\text { Oct }\end{array}$ & $\begin{array}{l}\text { Oct } \\
\text { Nov }\end{array}$ & $\begin{array}{l}\text { Oct } \\
\text { Nov }\end{array}$ \\
\hline \multirow{4}{*}{ 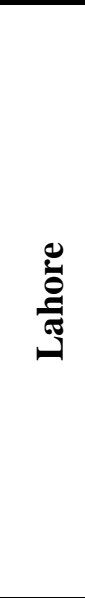 } & Duration & - & - & $\begin{array}{c}\text { Jan } \\
\text { Aug } \\
\text { to } \\
\text { Dec }\end{array}$ & $\begin{array}{l}\text { Sep } \\
\text { Dec }\end{array}$ & $\begin{array}{l}\text { Jul } \\
\text { Dec }\end{array}$ & $\begin{array}{l}\text { Apr } \\
\text { Dec }\end{array}$ & $\begin{array}{c}\text { Apr } \\
\text { Aug } \\
\text { to } \\
\text { Dec }\end{array}$ & $\begin{array}{c}\text { Mar } \\
\text { to } \\
\text { Dec }\end{array}$ \\
\hline & Minimum & $\begin{array}{c}\text { Jul } \\
\text { Aug } \\
\text { Sep } \\
\text { Dec }\end{array}$ & Dec & $\begin{array}{l}\text { Jan, } \\
\text { Aug } \\
\text { Dec }\end{array}$ & Dec & $\begin{array}{c}\text { Jul } \\
\text { Aug } \\
\text { Dec }\end{array}$ & $\begin{array}{c}\text { Apr } \\
\text { Jul }\end{array}$ & $\begin{array}{l}\text { Apr } \\
\text { Aug } \\
\text { Dec }\end{array}$ & $\begin{array}{c}\text { Mar } \\
\text { to } \\
\text { July } \\
\text { Sep }\end{array}$ \\
\hline & Moderate & Oct & $\begin{array}{l}\text { Sep } \\
\text { Oct }\end{array}$ & Sep & $\begin{array}{l}\text { Sep } \\
\text { Oct }\end{array}$ & Sep & $\begin{array}{l}\text { Aug } \\
\text { Nov } \\
\text { Dec }\end{array}$ & Sep & $\begin{array}{l}\text { Aug } \\
\text { Dec }\end{array}$ \\
\hline & Highest & Nov & Nov & $\begin{array}{l}\text { Oct } \\
\text { Nov }\end{array}$ & Nov & $\begin{array}{l}\text { Oct } \\
\text { Nov }\end{array}$ & $\begin{array}{l}\text { Sep } \\
\text { Oct }\end{array}$ & $\begin{array}{l}\text { Oct } \\
\text { Nov }\end{array}$ & $\begin{array}{l}\text { Oct } \\
\text { Nov }\end{array}$ \\
\hline \multirow{4}{*}{ 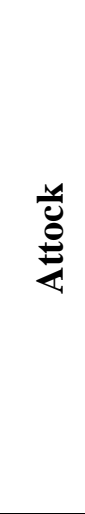 } & Duration & - & - & $\begin{array}{c}\text { Oct } \\
\text { to } \\
\text { Dec }\end{array}$ & $\begin{array}{c}\text { Oct } \\
\text { to } \\
\text { Dec }\end{array}$ & $\begin{array}{l}\text { Oct } \\
\text { Nov }\end{array}$ & $\begin{array}{c}\text { July } \\
\text { Sep } \\
\text { to } \\
\text { Dec }\end{array}$ & - & - \\
\hline & Minimum & Sep & Sep & Dec & Dec & & $\begin{array}{l}\text { Jul } \\
\text { Dec }\end{array}$ & - & Nov \\
\hline & Moderate & $\begin{array}{l}\text { Oct } \\
\text { Nov }\end{array}$ & $\begin{array}{l}\text { Oct } \\
\text { Nov }\end{array}$ & Oct & Oct & Oct & $\begin{array}{l}\text { Sep } \\
\text { Nov }\end{array}$ & - & - \\
\hline & $\begin{array}{c}\text { Highest } \\
\text { Continued }\end{array}$ & - & - & Nov & Nov & Nov & Oct & - & - \\
\hline
\end{tabular}


Naureen Zainab et al. / Geosfera Indonesia 6 (1), 2021, 77-95

\begin{tabular}{|c|c|c|c|c|c|c|c|c|c|}
\hline City & Dengue Risk & 2006 & 2007 & 2008 & 2009 & 2010 & 2011 & 2012 & 2013 \\
\hline \multirow{4}{*}{ 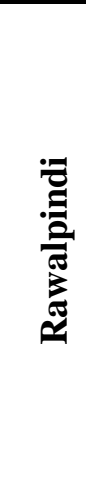 } & Duration & - & - & $\begin{array}{c}\text { Sep } \\
\text { To } \\
\text { Dec }\end{array}$ & $\begin{array}{c}\text { Sep } \\
\text { to } \\
\text { Dec }\end{array}$ & $\begin{array}{l}\text { Sep } \\
\text { Dec }\end{array}$ & $\begin{array}{c}\text { Jun } \\
\text { to } \\
\text { Dec }\end{array}$ & - & $\begin{array}{c}\text { Jun } \\
\text { to } \\
\text { Dec }\end{array}$ \\
\hline & Minimum & $\begin{array}{c}\text { Jul } \\
\text { Aug }\end{array}$ & Aug & Dec & Dec & $\begin{array}{l}\text { Sep } \\
\text { Dec }\end{array}$ & $\begin{array}{c}\text { Jun } \\
\text { Jul } \\
\text { Aug }\end{array}$ & - & $\begin{array}{c}\text { Jul } \\
\text { Aug } \\
\text { Dec }\end{array}$ \\
\hline & Moderate & Oct & $\begin{array}{l}\text { Sep } \\
\text { Oct }\end{array}$ & Sep & $\begin{array}{l}\text { Sep } \\
\text { Oct }\end{array}$ & & $\begin{array}{l}\text { Nov } \\
\text { Dec }\end{array}$ & - & Sep \\
\hline & Highest & Nov & Nov & $\begin{array}{l}\text { Oct } \\
\text { Nov }\end{array}$ & Nov & $\begin{array}{l}\text { Oct } \\
\text { Nov }\end{array}$ & $\begin{array}{l}\text { Sep } \\
\text { Oct }\end{array}$ & - & $\begin{array}{l}\text { Oct } \\
\text { Nov }\end{array}$ \\
\hline \multirow{4}{*}{ 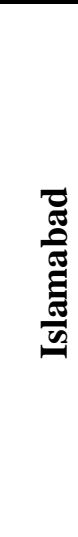 } & Duration & $\begin{array}{l}\text { Aug } \\
\text { to } \\
\text { Dec }\end{array}$ & - & $\begin{array}{c}\text { Sep } \\
\text { to } \\
\text { Dec }\end{array}$ & $\begin{array}{c}\text { Sep } \\
\text { to } \\
\text { Nov }\end{array}$ & $\begin{array}{l}\text { Sep } \\
\text { to } \\
\text { Dec }\end{array}$ & $\begin{array}{c}\text { Jun } \\
\text { to } \\
\text { Dec }\end{array}$ & - & $\begin{array}{l}\text { Aug } \\
\text { to } \\
\text { Dec }\end{array}$ \\
\hline & Minimum & - & - & Dec & Sep & Dec & $\begin{array}{c}\text { Jun } \\
\text { Jul } \\
\text { Aug } \\
\text { Dec }\end{array}$ & $\begin{array}{c}\text { Aug } \\
\text { to } \\
\text { Nov }\end{array}$ & $\begin{array}{l}\text { Aug } \\
\text { Sep } \\
\text { Dec }\end{array}$ \\
\hline & Moderate & $\begin{array}{l}\text { Sep } \\
\text { Oct }\end{array}$ & Oct & Sep & & $\begin{array}{l}\text { Sep } \\
\text { Oct }\end{array}$ & Nov & - & Oct \\
\hline & Highest & Nov & Nov & $\begin{array}{l}\text { Oct } \\
\text { Nov }\end{array}$ & $\begin{array}{l}\text { Oct } \\
\text { Nov }\end{array}$ & Nov & $\begin{array}{l}\text { Sep } \\
\text { Oct }\end{array}$ & - & Nov \\
\hline \multirow{4}{*}{ 豙 } & Duration & $\begin{array}{l}\text { Sep } \\
\text { to } \\
\text { Nov }\end{array}$ & & $\begin{array}{l}\text { Oct } \\
\text { Nov }\end{array}$ & $\begin{array}{l}\text { Sep } \\
\text { to } \\
\text { Nov }\end{array}$ & $\begin{array}{c}\text { Apr } \\
\text { Jul } \\
\text { to } \\
\text { Dec }\end{array}$ & - & - & - \\
\hline & Minimum & Dec & Dec & Dec & Sep & $\begin{array}{c}\text { Apr } \\
\text { Jul } \\
\text { Aug } \\
\text { Sep } \\
\text { Dec }\end{array}$ & $\begin{array}{l}\text { Sep } \\
\text { Oct }\end{array}$ & $\begin{array}{l}\text { Sep } \\
\text { Oct } \\
\text { Nov }\end{array}$ & - \\
\hline & Moderate & Oct & Sep & Oct & - & Oct & - & - & - \\
\hline & Highest & Nov & $\begin{array}{l}\text { Oct, } \\
\text { Nov }\end{array}$ & Nov & $\begin{array}{l}\text { Oct } \\
\text { Nov }\end{array}$ & Nov & - & - & - \\
\hline
\end{tabular}

\begin{tabular}{|c|c|c|c|c|c|c|c|c|c|}
\hline \multirow{4}{*}{ 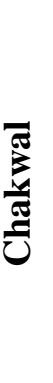 } & Duration & - & - & $\begin{array}{l}\text { No } \\
\text { Case }\end{array}$ & $\begin{array}{c}\text { Jan } \\
\text { Nov }\end{array}$ & $\begin{array}{c}\text { Sep } \\
\text { to } \\
\text { Nov }\end{array}$ & $\begin{array}{l}\text { Sep } \\
\text { to } \\
\text { Nov }\end{array}$ & - & - \\
\hline & Minimum & $\begin{array}{l}\text { Oct, } \\
\text { Nov }\end{array}$ & Sep & - & - & $\begin{array}{l}\text { Sep } \\
\text { Nov }\end{array}$ & - & - & - \\
\hline & Moderate & - & $\begin{array}{l}\text { Oct, } \\
\text { Nov }\end{array}$ & - & Jan & Oct & $\begin{array}{l}\text { Oct } \\
\text { Nov }\end{array}$ & - & - \\
\hline & Highest & Nov & - & - & Nov & - & Sep & - & - \\
\hline
\end{tabular}

Note : - = No case 


\subsection{Application - Web-Based GIS Alert System}

For Web-Based GIS Alert System application, a user can select URL localhost/dengue. The Dengue Support System will display. For login purposes, the user can click on the Login option. Before getting detailed information, the customer will be asked to enter the ID and password. If the user identification and password are wrongly entered, an error message will pop up, "Your attempt to login is not successful. Please try again," and the user will be asked to register until the correct information is typed in. This system would help to protect data security under study. The existing database had included eight years' data. The application was developed monthly, so a first select year and then the month, and then click/check the risk levels. Database contents and collections could be expanded in the future. After selecting the month and the year, the selected year's risk level will be displayed. Users can also zoom the areas concerned by clicking on the option Zoom Rectangle. This feature provides the consumer a general understanding of the environment impacted and theoretically affected.

One of the most important functions of this system was to find the current risk level of any district based upon the Breteau Index and temperature. By entering the Breteau Index and temperature, the system can find the current risk level of dengue of any Pakistan district by selecting the district in the drop-down list. Results shows that the user selected district Faisalabad entered Breteau Index 7.53 and temperature 21.4 and then clicked on Select, the risk level of Faisalabad was displayed. The blue color represents that it was at level 2.

The Dengue Alert System was capable of generating the reports of Risk levels of each month. The reports of the Risk level of dengue in September 2011 along with "Actions to be taken" at each level. The system was also capable of generating the Graphical representation of the Risk Level of each month (figure 6).

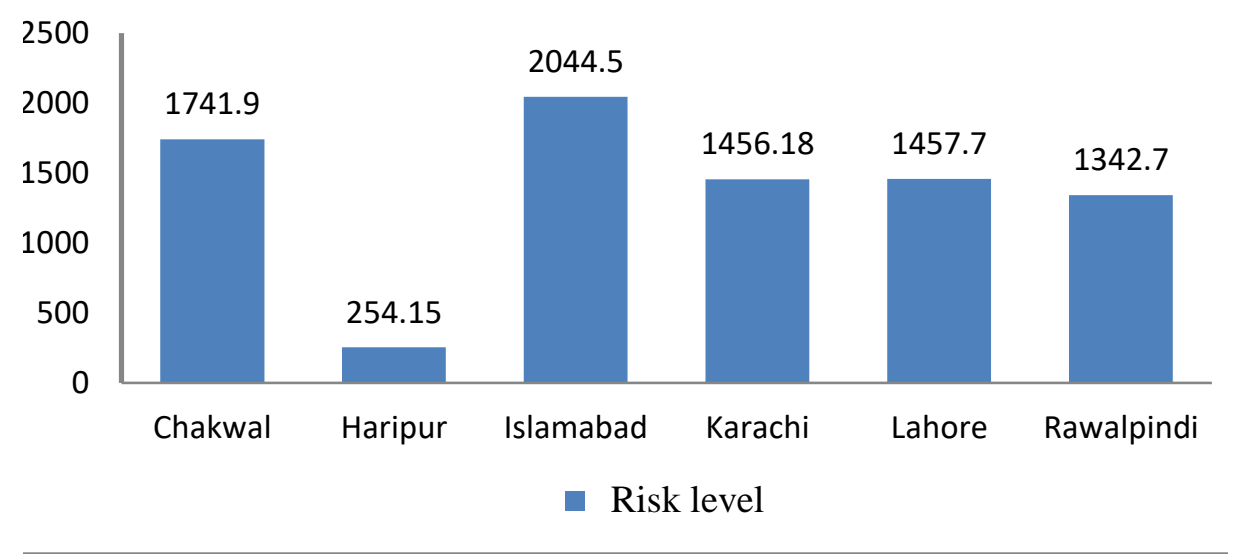

Figure 6. Graphical representation of risk level of September 2011 
It has been seen from the data and observed that high dengue indicators are in August, September, October, and November, i.e., after July, which have a high temperature in Pakistan. If the Breteau Scale is 0, the risk level will also be zero, regardless of how high the temperature is. It is concluded that risk level is mainly associated with breteau index, if breteau index is high, then risk level is also high, so this is the main reason due to which highest weightage is assigned to breteau index, but temperature also plays a significant role because risk level is high in mostly the months which have a high temperature. If the temperature is high, mosquito growth chances are also high because high temperature helps in the breeding of Aedine mosquitoes. There is no chance even if the temperature is very high without the existence of Aedine mosquitoes. For instance, if the temperature is similar for two cities, they have very different risk levels.

The device may be combined with other potential factors. Human population growth is a significant dengue consideration because the desert region containing many mosquitoes is not dangerous. If the weather around the house is suitable for dengue, then dengue infections will be high. The moisture and containers may be important influences. Eventually, mosquito species often play a part. The system is not without limitations. It is a web-based application, and for this application, internet connectivity must require. If the internet speed is slow, this application will not work properly because it requires high bandwidth.

According to dengue outbreaks, the likelihood of dengue is caused by many variables in real life including the virus and the climate. The application of temperature and breteau index offers one element of risk assessment, concentrating on exposure impact calculation alone. Certain considerations might be applied to the system's robustness.

Similar results/an online alert system (GIS) were developed. The interrelationship between various indices and temperature was measured by Wong et al., (2007), who observed that the inference forms the rationale for the generation of weighted overlays to define risk levels. Weighting can be adjusted to set the sensitivity of the alert system. They concluded that the alert system offers one objective means to defining the risk of dengue in a society, which would not be affected by the incidence of the infection itself

Similarly, Shen et al. (2015) conducted a study to explore the associations between the monthly number of dengue fever (DF) cases and possible risk factors in Guangzhou, a subtropical city of China. In their study, a total of 39,697 DF cases were detected in Guangzhou. Dengue fever incidence showed an obvious seasonal pattern, with most cases occurring from June to November. They observed that the current month's Breteau Index, average temperature, previous month's minimum temperature, and Tave were positively 
associated with Dengue fever incidence. They also concluded that the mosquito density, Tave, and Tmin play a critical role in dengue fever transmission in Guangzhou.

In another study, Liyanage et al., (2019) used an interrupted time-series design with a non-linear extension, and evaluated the impact of vector control interventions from June 22, 2014, to Dec 29, 2016, in Panadura, a high-risk MOH division in Western Province, Sri Lanka. They used dengue notification and larval survey data to estimate the reduction in Breteau index and dengue incidence before and after the intervention using two separate models, adjusting for time-varying confounding variables (i.e., rainfall, temperature, and the Oceanic Niño Index). They found that Breteau index is an essential index for controlling and measuring the extent of vector control in dengue transmission.

Bajwala et al (2020) conducted a study using mean temperature $\left({ }^{\circ} \mathrm{C}\right)$, relative humidity (\%), and precipitation (rainfall in $\mathrm{mm}$ ) as climatic parameters affecting vector ecology. They recorded the peak number of cases was recorded in the post-monsoon period. They proposed that presence of some serologically positive cases even during dry months in this study could probably be reflective of the year-round activity of the dengue vector.

Moreover, some advanced techniques, i.e., artificial intelligence-based mathematical model and fuzzy logic, could be a suitable option to implement control measures in dengueprone areas. Adak \& Jana (2021) developed an artificial intelligence-based mathematical model taking the three stegomyia indices, namely house index, Breteau index, and container index.

The project's concept was to build a Web-Based GIS Alert System for dengue data management and analysis, centralizing information and making it accessible to all relevant stakeholders before, during \& after a crisis situation. The system aims to ensure timely availability of information on health care services and project data, mapped accurately and with geographic features displayed, designed an alert system for users to visualize the spatial distribution of the risk of exposure to Aedine mosquito in the local setting. The system complements information on the incidence of infection and is a more objective way of defining risk levels. Overall, the system describes the risk levels of dengue infection in major cities of Pakistan, classifying them into three geographical regions, and can predict all Districts of Pakistan's risk levels. A web-based application was created from a synthesis of geospatial data related to Breteau index and temperature effect in Pakistan's major cities.

Future alignment of this program with practices of prevention and control of dengue fever will be important. This pilot project may be associated with the various government departments involved. Similar systems could be built and adapted to estimate exposure to other diseases, such as bird flu, for which environmental factors are critical for propagation. 
The program could become a tool for local, regional, and even national health authorities and other stakeholders in the long run.

\section{Conclusion}

The user interface of the dengue alert system was developed based upon MapGuide. The inter-relationship between Breteau Index and the temperature was developed using a web-based GIS application. Four different patterns mapping were developed for the risk of dengue, i.e., highest, high, medium, and minimal. Maps were created using pre-set criteria, and the map was shown as an image by the web browser.A high risk of dengue was found in August, September, October, and November, i.e., after July, in which had high temperature was noted. Risk level was found mainly associated with Breteau Index; if Breteau Index was high, then risk level was also high. When the Breteau Index equals zero, the risk level was zero, irrespective of the temperature rise. Temperature also played a significant role because the risk level was high, mainly in the months with high temperatures. There was no risk without Aedine mosquitoes' presence even if the temperature was very high. For instance, if the temperature was similar for two cities, they depicted very different risk levels. This study's significance is introducing a new method for expressing the alert system on a spatial scale. The web-based Alert system should no longer be expressed in statistical and textual formats, but that spatial graphics could be incorporated. In addition, the weighted overlay allows the users to weigh the contribution of factors affecting the exposure risk to dengue.

\section{Conflict of Interest}

The authors declare that there is no conflict of interest.

\section{Acknowledgments}

Authors gratefully acknowledge the support received from Dr. Mukhtar Senior Scientific Officer (Entomology), Ex. Head of Department of Zoonotic and Vector-Borne Diseases and thanks to Dr Jan Muhammad Director Pakistan Meteorological Department for monthly mean temperature data. We are thankful to Dr. M. Farrukh Sultan, DPC, EDOH, Lahore. The authors would also like to express their appreciation to Rana Naveed Mustafa (NARC), Naveed Yaqoob, Department of Mathematics, QAU Islamabad and Azmat Ali Sr. Project Manager ERP (IT/MIS) at Agribusiness Support Fund for their kind cooperation. This research was supported by the National Natural Science Foundation of China (No. 41871345). 


\section{References}

Abbas, F. (2013). Analysis of a historical (1981-2010) temperature record of the Punjab Province of Pakistan. Earth Interactions, 17(15), 1-23. https://doi.org/10.1175/2013EI000528.1.

Adak, S., \& Jana, S. (2021). A study on stegomyia indices in dengue control: a fuzzy approach. Soft Computing - A Fusion of Foundations, Methodologies and Applications, 25(1), 699-709. https://doi.org/10.1007/s00500-020-05179-x.

Asif, M., Tripathi, N. K., \& Ahmed, S. (2013). Towards Near Real Time Public Health Surveillance (A Decision Support System for Public Health Surveillance). International Journal of Computer Applications, 61(21), 45-50.

Attaway, D. F., Jacobsen, K. H., Falconer, A., Manca, G., \& Waters, N. M. (2016). Risk analysis for dengue suitability in Africa using the ArcGIS predictive analysis tools (PA tools). Acta tropica, 158, 248-257. https://doi.org/10.1016/j.actatropica.2016.02.018.

Bajwala, V. R., John, D., Rajasekar, D., Eapen, A., \& Murhekar, M. V. (2020). Burden of Dengue with Related Entomological and Climatic Characteristics in Surat City, Gujarat, India, 2011-2016: An Analysis of Surveillance Data. The American journal of tropical medicine and hygiene, 103(1), 142-148. https://doi.org/10.4269/ajtmh.19-0967.

Bowman, L. R., Runge-Ranzinger, S., \& McCall, P. J. (2014). Assessing the Relationship between Vector Indices and Dengue Transmission: A Systematic Review of the Evidence. PLoS Neglected Tropical Diseases, 8(5). https://doi.org/10.1371/journal.pntd.0002848.

Bozdogan Sert, E., Kaya, E., Adiguzel, F., Cetin, M., Gungor, S., Zeren Cetin, I., \& Dinc, Y. (2021). Effect of the surface temperature of surface materials on thermal comfort: a case study of Iskenderun (Hatay, Turkey). Theoretical and Applied Climatology, 1-11. https://doi.org/10.1007/s00704-021-03524-0.

Cetin, M. (2019). The effect of urban planning on urban formations determining bioclimatic comfort area's effect using satellitia imagines on air quality: a case study of Bursa city. Air Quality, Atmosphere \& Health, 12(10), 1237-1249. https://doi.org/10.1007/s11869-019-00742-4.

Cetin, M., Adiguzel, F., Gungor, S., Kaya, E., \& Sancar, M. C. (2019). Evaluation of thermal climatic region areas in terms of building density in urban management and planning for Burdur, Turkey. Air Quality, Atmosphere \& Health, 12(9), 1103-1112. https://doi.org/10.1007/s11869-019-00727-3.

Cetin, M. (2015). Using GIS analysis to assess urban green space in terms of accessibility: case study in Kutahya. International Journal of Sustainable Development \& World Ecology, 22(5), 420-424. https://doi.org/10.1080/13504509.2015.1061066.

Chang, A. Y., Parrales, M. E., Jimenez, J., Sobieszczyk, M. E., Hammer, S. M., Copenhaver, D. J., \& Kulkarni, R. P. (2009). Combining google earth and GIS mapping technologies in a dengue surveillance system for developing countries. International Journal of 
Health Geographics, 8(1), 1-11. https://doi.org/10.1186/1476-072X-8-49.

Gubler, D. J. (2006). Dengue/dengue haemorrhagic fever: history and current status. In Novartis foundation symposium (Vol. 277, p. 3). Chichester; New York; John Wiley.

Gubler, D. J., Ooi, E. E., Vasudevan, S., \& Farrar, J. (2014). Dengue and dengue hemorrhagic fever. Oxfordshire : CABI.

Gungor, S., Cetin, M., \& Adiguzel, F. (2020). Calculation of comfortable thermal conditions for Mersin urban city planning in Turkey. Air Quality, Atmosphere and Health, 1-8. https://doi.org/10.1007/s11869-020-00955-y.

Kahn, T. C., Cameron, J. T., \& Giffen, M. B. (1975). Methods and evaluation in clinical and counseling psychology. Elmsford, NY: Pergamon Press.

Kaya, E., Agca, M., Adiguzel, F., \& Cetin, M. (2019). Spatial data analysis with R programming for environment. Human and Ecological Risk Assessment, 25(6), 15211530. https://doi.org/10.1080/10807039.2018.1470896.

Liyanage, P., Rocklöv, J., Tissera, H., Palihawadana, P., Wilder-Smith, A., \& Tozan, Y. (2019). Evaluation of intensified dengue control measures with interrupted time series analysis in the Panadura Medical Officer of Health division in Sri Lanka: a case study and cost-effectiveness analysis. The Lancet. Planetary Health, 3(5), e211-e218. https://doi.org/10.1016/S2542-5196(19)30057-9.

Mukhtar, M., Tahir, Z., Baloch, T., Mansoor, F., \& Kamran, J. (2011). Entomological investigations of dengue vectors in epidemic-prone districts of Pakistan during 20062010. World Health Organization Regional Publications. South East Asia Series.

Novotny, V., Miller, S. E., Hulcr, J., Drew, R. A. I., Basset, Y., Janda, M., ... Weiblen, G. D. (2007). Low beta diversity of herbivorous insects in tropical forests. Nature, 448(7154), 692-695. https://doi.org/10.1038/nature06021.

Olubadewo-Joshua, O., \& Ugom, K. M. (2019). Application of Geospatial Techniques in the Locational Planning of Health Care Centers in Minna, Nigeria. Geosfera Indonesia, 3(3), 59-72. https://doi.org/10.19184/geosi.v3i3.8754.

Shen, J. C., Luo, L., Li, L., Jing, Q. L., Ou, C. Q., Yang, Z. C., \& Chen, X. G. (2015). The impacts of mosquito density and meteorological factors on dengue fever epidemics in Guangzhou, China, 2006-2014: A time-series analysis. Biomedical and Environmental Sciences, 28(5), 321-329. https://doi.org/10.3967/bes2015.046.

Sirisena, P., Noordeen, F., Kurukulasuriya, H., Romesh, T. A., \& Fernando, L. K. (2017). Effect of climatic factors and population density on the distribution of dengue in Sri Lanka: A GIS based evaluation for prediction of outbreaks. PloS One, 12(1), e0166806. https://doi.org/10.1371/journal.pone.0166806.

Burney, S. A., Barakzai, M. A. K., \& James, S. E. (2020). Forecasting Monthly Maximum Temperature of Karachi City using Time Series Analysis. Pakistan Journal of Engineering, Technology \& Science, 7(2). https://doi.org/10.22555/pjets.v7i2.2439. 
Thompson, R. N., Gilligan, C. A., \& Cunniffe, N. J. (2016). Detecting Presymptomatic Infection Is Necessary to Forecast Major Epidemics in the Earliest Stages of Infectious $\begin{array}{llll}\text { Disease Outbreaks. PLoS Computational } & \text { Biology, }\end{array}$ https://doi.org/10.1371/journal.pcbi.1004836.

Tran, B. L., Tseng, W. C., Chen, C. C., \& Liao, S. Y. (2020). Estimating the threshold effects of climate on dengue: A case study of Taiwan. International Journal of Environmental Research and Public Health, 17(4), 1-17. https://doi.org/10.3390/ijerph17041392.

Udayanga, L., Gunathilaka, N., Iqbal, M. C. M., Najim, M. M. M., Pahalagedara, K., \& Abeyewickreme, W. (2018). Empirical optimization of risk thresholds for dengue: An approach towards entomological management of Aedes mosquitoes based on larval indices in the Kandy District of Sri Lanka. Parasites and Vectors, 11(1), 368. https://doi.org/10.1186/s13071-018-2961-y.

Wong, N. S., Law, C. Y., Lee, M. K., Lee, S. S., \& Lin, H. (2007). An Alert System for Informing Environmental Risk of Dengue Infections. In P. C. Lai \& A. S. H. Mak (Eds.), GIS for Health and the Environment: Development in the Asia-Pacific Region With 110 Figures (pp. 171-183). Springer Berlin Heidelberg. https://doi.org/10.1007/978-3-540-71318-0_12.

Zavlavsky, I. (2000). A New Technology for Interactive Online Mapping with Vector Markup and XML. Cartographic Perspectives, O(37), 65-77-77. https://doi.org/10.14714/CP37.810. 